$\mathrm{A} \mathrm{J}_{\mathrm{sins}} \mathrm{H}$

Article history :

Received : 04.06.2014

Revised : 20.03.2015

Accepted : 06.04.2015

Members of the Research Forum

Associated Authors:

${ }^{1}$ Department of Horticulture, Faculty

of Agriculture, Annamalai

University, ANNAMALAI NAGAR

(T.N.) INDIA
Author for correspondence :

M. SUDHAKAR

Department of Horticulture, Faculty

of Agriculture, Annamalai

University, ANNAMALAI NAGAR

(T.N.) INDIA

Email : sudhaflora@yahoo.com
THEASIAN JOURNAL OF HORTICULTURE

Volume 10 | Issue 1 | June, 2015 | 36-40

Visit us -www.researchjournal.co.in

\title{
Studies on the influence of planting season and weather parameters on growth parameters of two different varieties of $G$. grandiflorus L.
}

\section{SUDHAKAR AND S. RAMESH KUMAR ${ }^{1}$}

ABSTRACT : An experiment was conducted in Factorial Randomized Block Design to investigate the growth and flowering of two gladiolus varieties $\left(\mathrm{V}_{1}\right.$-White friendship and $\mathrm{V}_{2}$-American beauty) in early and late growing seasons. The seasons compared were, planting by first week of July $\left(S_{1}\right)$, September $\left(S_{2}\right)$, December $\left(S_{3}\right)$ and February $\left(S_{3}\right)$. The growth parameters were significantly influenced by the per se and interaction effects of different planting seasons and varieties of gladiolus. Among the varieties, White friendship $\left(\mathrm{V}_{1}\right)$ produced the highest values of all the growth parameters viz., days to sprouting, sprouting percentage, plant height, number of leaves per plant, leaf area, dry matter production and days to spike emergence. Among different seasons compared, December planting $\left(S_{3}\right)$ evinced better performance. The results of the correlation between the mean value of growth parameters in different seasons and weather parameters exhibited that the plant height and sprouting percentage were negatively correlated with maximum temperature (within a range of $29.9^{\circ} \mathrm{C}-35.02^{\circ} \mathrm{C}$ ), minimum temperature (within a range of $22.12^{\circ} \mathrm{C}-25.70^{\circ} \mathrm{C}$ ) and bright sunshine hours (within a range of $6.25-8.85 \mathrm{hrs}$ ). However, days taken for sprouting was positively correlated with these weather parameters.

KEY WORDS : Gladiolus sp., Season, Weather parameters, Growth parameters, Dry matter production

HOW TO CITE THIS ARTICLE : Sudhakar, M. and Ramesh Kumar, S. (2015). Studies on the influence of planting season and weather parameters on growth parameters of two different varieties of $G$. grandiflorus L. Asian J. Hort., 10(1) : 36-40. 